\title{
TRÊS CASOS DE ACONSELHAMENTO GENÉTICO NO BRASIL
}

\author{
THREE STUDY CASES OF GENETIC \\ COUSELING IN BRASIL
}

\section{Debora de Sa Ribeiro Aymore ${ }^{1}$}

RESUMO: Abordando a aplicação tecnológica como uma prática contextualizada social e historicamente, e desenvolvida em determinadas instituições, refletimos sobre três casos de aconselhamento genético realizado no Centro de Estudos do Genoma Humano e Células-Tronco. Segundo Mayana Zatz, professora titular de genética do Instituto de Biociências da Universidade de São Paulo, o aconselhamento genético é capaz de diminuir o risco de casais terem seus filhos afetados por doenças (cf. ZATZ, 2000, p. 29). Porém, podemos ressaltar que, além da prevenção, o aconselhamento genético pode levantar informações incidentais, tais como sobre falsa paternidade ou sobre relações de incesto. $\mathrm{O}$ conflito ético derivado de informações incidentalmente obtidas envolve redes complexas de valores, tanto dos responsáveis pelos atendimentos, quanto dos pacientes e de seus familiares. Assim, dado a obtenção de tais informações, é necessário articular os valores envolvidos, tendo em vista a manutenção (ou não) do sigilo médico e a realização do menor dano possível aos pacientes e aos seus familiares. Juntamente com o sigilo médico, outros valores sociais estão implicados nas situações controversas, tais como a proteção à intimidade individual, à família e à criança e ao adolescente. Visando a contextualização dos três casos de aconselhamento, abordamos, entre outras leis, a Constituição Federal de 1988, o Código de Ética Médica e o Estatuto da Criança e do Adolescente, buscando basear nossa análise em valores considerados em alta estima social no Brasil.

Palavras-chave. Aconselhamento genético. Falsa paternidade. Incesto. Informações incidentais. Sigilo médico.

\begin{abstract}
Approaching technological applications as a social-historical contextualized practice, and developed within certain institutions, we reflect on three cases of genetic counseling performed at the Human Genome and Stem-Cells Research Center. According to Mayana Zatr, chair professor in Genetics at Biosciences Institute of University of São Paulo, genetic counseling is capable of decrease risks of couples' descendants affected by genetic diseases (cf. ZATZ, 2000, p. 29). However, we can also highlight that, beyond prevention, genetic counselling can raise incidental information, such as false paternity or incestuous relations. The ethical conflict derived from incidental information involves a complex set of values defended by institutional representatives, as well as by patients and families. Therefore, incidental information once acquired, requires values articulation specially related to the maintenance (or not) of medical confidentiality, and aiming to cause the least damage possible to patients and families. Therefore, along with medical confidentiality, other social values are involved in controversial situations, such as the individual intimacy, family, and children and adolescent protections. In order to contextualize the three study cases, we approach, among others laws, The Brazilian Federal Constitution of 1988, the Code of Medical Ethics and
\end{abstract}

\footnotetext{
${ }^{1}$ Professora substituta do Departamento de Filosofia da Universidade Federal do Paraná (UFPR), colaboradora e orientadora no Curso de Especialização em Estudos Culturais e Políticas Públicas (Poscult/UNIFAP). Membro da Associação Filosófica Scientiae Studia, pesquisadora do Núcleo de Estudos da Cultura Técnica e Científica (NECTeC/ UFPR), do Grupo de Pesquisa Ética e Política (UEAP) e do Estudos Interdisciplinares em Cultura e Políticas Públicas (UNIFAP). Orcid: http://orcid.org/0000-0003-1384-6681
} 
the Statute of Children and Adolescents, to base our analysis on highly socially estimated values in Brazil. Keywords. Genetic Counseling. False Paternity. Incest. Incidental information. Medical confidentiality.

\section{INTRODUÇÃO}

O aconselhamento genético é uma realidade no Brasil. Praticado no Centro de Estudos do Genoma Humano e Células-Tronco (CEGH-CEL) vinculado ao Instituto de Biociências da Universidade de São Paulo, ele é um serviço oferecido à comunidade. Desde o ano de 2000, foram atendidas mais de 50 mil famílias, segundo o relato da geneticista Mayana Zatz (cf. 2011, p. 27-8). Outra contagem fornecida no site de divulgação científica do Projeto Semear, vinculado ao CEGH-CEL, o aconselhamento genético já alcançou, desde o ano de 1968, o número expressivo de 100 mil famílias atendidas. ${ }^{2}$ Em qualquer das contagens, a quantidade de aconselhamentos realizados impressiona. Além disso, deve-se considerar que tal serviço é uma das atividades realizadas no CEGH-CEL, pois os cientistas e demais profissionais também se dedicam à pesquisa e à divulgação científica, com especial atenção à produção e disponibilização de materiais didáticos para a educação. ${ }^{3}$

Como podemos definir o aconselhamento genético? Segundo Zatz, ele é resultado de uma investigação que tem como objetivo fazer com que as pessoas concernidas, sejam elas os pacientes ou seus familiares, recebam informações necessárias para capacitá-los a tomar decisões de forma consciente, autônoma e responsável (cf. ZATZ, 2011, p. 54), especialmente sobre a possibilidade de gerarem ou não descendentes, pois em vários casos há o risco de transmissão de características genéticas anormais. No entanto, a expressão é imprecisa, uma vez que o “(...) geneticista não aconselha. Ele deve apenas cuidar para que as possibilidades de escolha de seus pacientes sejam informadas e esclarecidas" (ZATZ, 2011, p. 30).

Não se trata, portanto, de tomar decisões em nome dos pacientes com base nas informações genéticas obtidas, mas apenas de informá-los de modo acurado, para que, com base no esclarecimento, por exemplo, sobre a probabilidade de que seus descendentes desenvolvam determinadas doenças genéticas ou sobre a gravidade das mesmas, os pacientes estejam mais capacitados a tomar decisões sobre gerar ou não descendentes, dado o enfrentamento com o risco de que a prole se torne ou portadora assintomática ou que efetivamente desenvolva doenças genéticas. Os casos tratados pelo CEGH-CEL não se dirigem, assim, para o melhoramento genético ${ }^{4}$ de qualquer tipo de traço genético e nem mesmo a detecção de genes cuja repercussão fenotípica pode ser considerada secundária, tais como a cor dos olhos, da pele ou do cabelo. Trata-se antes da identificação de anormalidades genéticas com graves

\footnotetext{
2 Disponível em: <http://www.ib.usp.br/biologia/projetosemear/diferentes/>. Acesso em: 26/03/2015.

${ }^{3}$ Mariana Toledo Ferreira em estudo sociológico recente sobre a institucionalização da pesquisa genética no Brasil afirma que o CEGH-CEL é constituído por cerca de 90 pessoas, entre professores, pesquisadores, médicos, técnicos especializados e estudantes de graduação e de pós-graduação. Dentre eles existem doze pesquisadores seniores, sendo que dez são do Instituto de Biociências da USP, um é médico e livre docente do Hospital das Clínicas da Faculdade de Medicina da USP e o outro está ligado ao Instituto de Biociências na USP (cf. FERREIRA, 2013, p. 12-13). Essa coleção de membros participantes do centro de estudos já oferece uma primeira impressão sobre a quantidade e a complexidade de atividades nele desenvolvidas.

${ }^{4}$ Michael J. Sandel considera como exemplos de aplicações da genética molecular para o melhoramento as bioengenharias realizadas para melhoria da musculatura, da memória e da altura (cf. SANDEL, 2013, p. 23-31). A questão que permeia tais exemplos é que, embora originalmente dirigidas para amenizar ou curar doenças, tais como, respectivamente, as derivadas de doenças degenerativas da musculatura, as decorrentes do envelhecimento ou mesmo de deficiências de hormônio de crescimento, abrem a possibilidade de serem aplicadas em organismos saudáveis, tendo em vista a formação de organismos acima da média.
}

PRACS: Revista Eletrônica de Humanidades do Curso de Ciências Sociais da UNIFAP https://periodicos.unifap.br/index.php/pracs ISSN 1984-4352 Macapá, v. 12, n. 1, p. 49-63, jan./jun. 2019 
repercussões, como é o caso da doença de Huntington (ou coreia de Huntington), a Fibrose quística (ou cística) e a anemia drepanocítica (ou de células falciformes). ${ }^{5}$

Zatz afirma que seus interesses iniciais de pesquisa a dirigiram para o estudo da distrofia muscular de Duchenne, que conjuga duas características preocupantes tanto para o paciente, quanto para os pais: a primeira é a de ser uma “(...) doença degenerativa letal que causa perda progressiva da musculatura, para a qual não se tem cura” (ZATZ, 2011, p. 23); e a segunda é a de que em "(...) dois terços [dos casos ela] é transmitida pela mãe, que é portadora clinicamente normal, mas pode passar o gene defeituoso para os filhos do sexo masculino, que têm 50\% de chance de herdá-lo e serem afetados" (ZATZ, 2011, p. 55).

Por um lado, o aconselhamento genético desenvolve atividade biotecnológica, ou seja, uma aplicação médica a partir do conhecimento produzido pela pesquisa em genética molecular. E, por outro lado, dirige-se ao atendimento de pessoas, cujo foco está na prevenção de transmissão de doenças genéticas, exercitando uma forma de eugenia negativa. ${ }^{6}$ Consequência disso é que os geneticistas e os pacientes vinculam-se segundo relações que expressam direitos e deveres e que estão regulados no Brasil por uma complexa teia normativa formada, entre outros, pela Constituição Federal de 1988 e pelo Código de Ética Médica, bem como por orientações gerais adotadas pelo CEGH-CEL, como consequência da ampla experiência prática dos geneticistas com o aconselhamento genético. A própria necessidade de instituir normativamente os procedimentos a serem adotados (ou mesmo evitados) nessa relação de atendimento é indicativa das diferentes perspectivas de valor existentes que, por sua vez, podem levar a conflitos éticos.

No que segue, apresentamos três casos de aconselhamento genético que suscitaram conflitos éticos. Interessa-nos ressaltar que, da perspectiva dos responsáveis pelo atendimento, o conflito se apresenta quando o procedimento de escaneamento genético permite explicitar casos, por exemplo, de falsa paternidade ou mesmo de incesto, cuja divulgação conflita com o dever de sigilo médico. E, da perspectiva dos pacientes, que há o direito à privacidade, embora representado parcialmente, na medida em que com sua busca voluntária e consentida pelo aconselhamento autoriza que suas informações genéticas sejam de conhecimento ao menos dos geneticistas. ${ }^{7}$ Assim, a questão que paira nos três casos tem como base o conflito entre

\footnotetext{
${ }^{5}$ A doença de Huntington tem seu início na meia-idade e é caracterizada pelos movimentos espasmódicos, pela perda de neurônios e, em suas etapas mais avançadas, várias funções são afetadas, de modo que o paciente passa a precisar de assistência médica em tempo integral (cf. Manual Merck. Disponível em: <http://www.manualmerck.net ?id=93\&cn=876\&ss=Huntington $>$. Acesso em 17/05/2015); a Fibrose cística faz com que determinadas glândulas produzam secreções de modo anormal, afetando o tubo digestivo e os pulmões. Apenas 35\% das pessoas que sofrem dela chegam à fase adulta, afetando igualmente pessoas do sexo feminino e masculino (cf. Manual Merck. Disponível em: <http://www.manualmerck.net/?id=69>. Acesso em 17/05/2015); e, na anemia drepanocítica, o indivíduo apresenta um gene normal e outro anormal, produzindo glóbulos vermelhos normais e de estrutura anômala (cf. Manual Merck. Disponível em: <http:/ /www.manualmerck.net/?id=28\&cn=517\&ss >. Acesso em 17/05/2015).

${ }^{6}$ Jürgen Habermas afirma que a eugenia negativa é aquela em que se busca evitar determinados traços genéticos considerados especialmente vinculados à impossibilidade de o indivíduo exercer seu ideal de vida plenamente. Porém, essa aplicação poderia desbordar em eugenia positiva, ou seja, no estímulo de determinados traços genéticos desejáveis, o que, inclusive, pode se vincular ao discurso liberal, implicando em uma ausência de limitações, ou uma anuência tácita, a toda e qualquer prática eugênica (cf. HABERMAS, 2012, p. 63).

7 Zatz informa que, segundo a orientação vigente no Brasil, ninguém pode ser obrigado a receber o aconselhamento genético e, portanto, sua realização está condicionada ao respeito ao princípio da busca voluntária. Porém, há exceções a esse princípio, como no caso dos recém-nascidos que são, por obrigatoriedade de lei, testados para a fenilcetonúria, o hipotireoidismo congênito, a anemia falciforme e a fibrose cística (cf. ZATZ, 2011, p. 29) através do teste do pezinho (cf. Biblioteca Virtual em Saúde. Disponível em: <http://bvsms.saude.gov.br/bvs/dicas/180_teste_pezinho.html>. Acesso em 17/05/2015).
}

PRACS: Revista Eletrônica de Humanidades do Curso de Ciências Sociais da UNIFAP https://periodicos.unifap.br/index.php/pracs ISSN 1984-4352 Macapá, v. 12, n. 1, p. 49-63, jan./jun. 2019 
valores do sigilo médico, da privacidade ou intimidade, e questões relativas à proteção à família e à criança e ao adolescente.

A seguir apresentamos os três casos de aconselhamento genético, bem como os conflitos éticos que surgem a partir da obtenção do que denominamos informações incidentais, ou seja, informações obtidas por ocasião do aconselhamento genético e que podem ou não derivar do escaneamento genético. Além disso, sua relevância se dá devido aos impactos negativos que podem ser gerados a partir de sua divulgação (por exemplo, dissolução de núcleos familiares, segregação ou impacto para os projetos de vida dos pacientes). Tornar-se-á claro a partir de nosso texto que buscamos um enfoque particular, local e contextualizado na análise da aplicação do aconselhamento genético no CEGH-CEL, de modo que recorreremos à legislação brasileira para mostrar como essa atividade está inserida nas orientações legislativas do Brasil que, por si mesmas, apresentam determinadas inclinações valorativas.

Segundo Ferreira (2013), o CEGH-CEL se dedica não apenas à pesquisa e à difusão, como apresenta a atividade de transferência tecnológica através especialmente do aconselhamento genético que realiza. Desse modo, foram inicialmente dois elementos que chamaram nossa atenção para essa última atividade. Primeiramente, o fato de que por meio da aplicação tecnológica, o aconselhamento genético mantém o contato direito com os pacientes e seus familiares, permitindo que nossa análise destacar os possíveis conflitos resultantes da defesa de valores sociais diferentes nas decisões sobre o sigilo ou divulgação das informações incidentais. E, em segundo lugar, a riqueza ético-valorativa que está implicada nas informações obtidas através da atividade de aconselhamento genético que, por mais técnica que seja, apresentam resultados sociais positivos e, por vezes, negativos.

Obviamente que na maioria dos casos atendidos pelo CEGH-CEL vigora a experiência e o bom-senso dos profissionais pertencentes ao centro, que se dedicam ao exercício de uma medicina preventiva através no aconselhamento genético. Porém, cabe ressaltar que o Código de Ética Médica prescreve para o caso de novas tecnologias um princípio de precaução, na medida em que afirma que na "(...) aplicação dos conhecimentos criados pelas novas tecnologias, (...) o médico zelará para que as pessoas não sejam discriminadas por nenhuma razão vinculada a herança genética, protegendo-as em sua dignidade, identidade e integridade" (XXV, Código de Ética Médica).

Precavendo-se, assim, não quando ao uso legítimo de novas tecnologias para o incremento da saúde e do bem-estar humanos, mas sim quando aos excessos que podem resultar a partir das técnicas cada vez mais aprimoradas de detecção da probabilidade genética de desenvolvimento de determinadas doenças, o Código de Ética Médica propõe a restrição de certas aplicações na Medicina; limitações essas que estão, por sua vez, dirigidas à manutenção da dignidade, da identidade e da integridade humanas. Daí que a nossa reflexão sobre o conflito de valores gerados a partir da obtenção de informações incidentais dos pacientes não visa de descaracterizar o rigor da aplicação imparcial do conhecimento científico por meio do aconselhamento, ou mesmo a objetividade ou a sensibilidade ética com que são realizados os aconselhamentos genéticos. O que propomos é uma tarefa reflexiva centrada na articulação dos valores que emergem a partir da obtenção de informações incidentais, em sua situação de conflito entre distintos valores sociais.

Pressupomos, assim, que as ações, ou mais especificamente as decisões tomadas em contexto social, exigem razões, ou seja, justificativas racionais para que certo curso de ação (e não outro) seja adotado em questões práticas. O ponto que analisamos no estudo dos três casos 
de aconselhamento genético é, em especial, sobre o dever de manutenção ou de quebra do sigilo médico. Assim, na medida em que socialmente oferecemos razões para a ação ou para as decisões sobre o curso de ação, pressupomos que nossas razões serão ouvidas e avaliadas por outros, que poderão concordar ou discordar de nossa perspectiva.

\section{SÔNIA, PEDRO E A FALSA PATERNIDADE}

Como vimos, segundo a orientação vigente no Brasil, ninguém pode ser obrigado a receber o aconselhamento genético e, portanto, sua realização está condicionada ao respeito ao princípio da busca voluntária (cf. ZATZ, 2011, p. 29). O que, em outras palavras, significa que as próprias pessoas devem buscar o atendimento desde que considerem que estão em situação de risco de gerar descendentes com doenças genéticas. Os três casos que analisaremos a seguir foram de atendimentos ocorridos no CEGH-CEL, e descritos com maior ou menor detalhamento por Zatz (2011). Para manter a confidencialidade da relação médico-paciente, os nomes dos pacientes foram substituídos por nomes fictícios (cf. ZATZ, 2011, p. 31), o que, no entanto, não torna menos relevante a análise das consequências éticas de tais atendimentos, uma vez que os mesmos envolveram, de fato, pessoas reais.

O primeiro é o caso de Sônia, cujo pai era portador da coreia de Huntington, doença degenerativa dos neurônios que só se manifesta a partir de 40 anos de idade, que não possui cura e que pode afetar tanto homens quanto mulheres. O que Sônia desejava era uma orientação sobre a probabilidade de ela gerar descendente com a mesma doença de seu pai. Porém, os geneticistas se depararam com uma informação que impactava diretamente na razão pela qual Sônia buscara o atendimento no CEGH-CEL. Os profissionais foram informados pela mãe de Sônia que, na verdade, sua filha e seu marido não tinham relação de parentesco biológico, mas que sua filha desconhecia esse fato (cf. ZATZ, 2011, p. 42-43).

A circunstância era tal que, embora a equipe de geneticistas tivesse o conhecimento privilegiado sobre o fato de o pai de Sônia não ser seu pai biológico, o que eliminaria suas preocupações, não lhes era possível nem quebrar o sigilo da informação e nem mesmo dizer para a mãe o que ela deveria fazer, devido a própria ideia de que o aconselhamento genético informa, mas deve deixar que a decisão seja tomada pelas pessoas concernidas (pacientes ou parentes). O caso de Sônia configura, portanto, um caso de "falsa paternidade", o que significa que seu pai biológico era outra pessoa que não aquela que até então considerava como seu pai.

O segundo caso é de um paciente de leucemia ${ }^{8}$ que, em busca de doador compatível, descobriu-se que não era filho biológico de seu pai. Mais grave talvez que o caso de Sônia, pois, após o escaneamento genético, também foi descoberta a incompatibilidade genética em relação à mãe. O que levou à conclusão de que, na verdade, Pedro havia sido trocado na maternidade (cf. ZATZ, 2011, p. 45). Assim, a família em questão teve que lidar ao mesmo tempo com a leucemia que acometia Pedro e com a informação incidentalmente obtida pela investigação genética sobre a falsa paternidade, nesse caso, aplicada tanto ao pai, quanto à mãe. Essas informações incidentais obtidas levantam, nos casos de Sônia e Pedro, questões complexas sobre as relações entre os membros daquela família, que até então acreditavam partilhar relação de paternidade biológica, bem como questões éticas sobre confidencialidade no exercício do aconselhamento genético, gerando o conflito ético sobre a divulgação ou não da falsa

8 Trata-se de uma “(...) doença relacionada ao sangue, que pode ser curada com o transplante de medula óssea ou sangue do cordão umbilical de doador compatível” (cf. ZATZ, 2011, p. 44).

PRACS: Revista Eletrônica de Humanidades do Curso de Ciências Sociais da UNIFAP https://periodicos.unifap.br/index.php/pracs ISSN 1984-4352 Macapá, v. 12, n. 1, p. 49-63, jan./jun. 2019 
paternidade. ${ }^{9}$

Desse modo, é possível observar que existem consequências do aconselhamento genético que extrapolam o âmbito exclusivamente técnico. Nos casos de Sônia e de Pedro, a investigação genética levou ao questionamento da paternidade que, em princípio, não eram o objetivo principal da investigação. Por essa razão, tais informações foram obtidas de modo incidental quando da realização da investigação genética. Porém, não podemos negar o seu impacto sobre a vida do paciente e de seus familiares que buscavam, inicialmente, ou a informação sobre a probabilidade de Sônia gerar descendente com a coreia de Huntington, ou a informação sobre um doador compatível e obtendo-se de modo não intencional a informação sobre a falsa paternidade.

Em que pese orientados pela busca de diminuir a incidência de condições negativas advindas, no primeiro caso, da possibilidade de geração de filho por Sônia com a anomalia genética que desenvolve a coreia de Huntington e, no segundo caso, do quadro clínico leucemia de Pedro, os relatos dos casos indicam que a decisão de divulgar ou não a falsa paternidade foi deixada a cargo dos geneticistas ou responsáveis pelo atendimento e, em parte, a cargo dos familiares. E que, devido a essa informação incidentalmente obtida, geneticistas e familiares estiveram claramente diante de um dilema ético causado pelo choque entre pelo menos dois valores sociais: o da proteção da família versus o do direito à intimidade. ${ }^{10}$

É justamente sobre o direito à intimidade dos indivíduos que impactam questões relativas à confidencialidade. $\mathrm{E}$, entre os danos principais relacionados à quebra da confidencialidade está a discriminação baseada no mau uso das informações obtidas pela pesquisa genética (cf. ZATZ, 2011, p. 31). Por isso, segundo ZATZ, há uma orientação de limitar possibilidade de realização de testes genéticos em crianças, pois, mesmo que a investigação seja solicitada pelos pais, as crianças podem ser apenas portadoras assintomáticas de doenças para as quais não se tem cura. A justificativa de tal limitação baseia-se no fato de que a divulgação da descoberta de que a criança é portadora de um gene de uma doença que, por exemplo, se manifestará apenas em sua vida adulta, pode interferir em suas decisões sobre o futuro (cf. ZATZ, 2011, p. 32). Embora essa orientação possa ser debatida, cabe aqui apenas ressaltar que o valor do reconhecimento em mais alta estima é o da proteção ao desenvolvimento digno da criança (Art. $3^{\circ}$, Estatuto da Criança e do Adolescente).

\footnotetext{
${ }^{9}$ A relação de paternidade implica em obrigações, portanto, que transcendem a infância e a adolescência visando a provisão de condições (inclusive materiais) para o desenvolvimento digno dos indivíduos. No Brasil o debate sobre a paternidade biológica e socioafetiva, segundo três correntes principais: a corrente biológica se baseia no $6^{\circ}$ do Art. 227 da Constituição, reconhecendo aos filhos, reconhecidos ou não o direito à herança; a adoção à brasileira permite que filho legalmente adotado solicite investigação dos pais biológicos em busca de reconhecimento, o que, inclusive, pode gerar todas as consequências legais, com a anulação do registro de nascimento dos pais adotivos; e, finalmente, a corrente socioafetiva, que busca, entre outros, evitar demandas meramente patrimoniais (Disponível em: < http://www.conjur.com.br/2013jan-17/stf-decidira-disputa-entre-paternidade-socioafetiva-biologica >. Acesso em: 06/11/2015). Não desenvolveremos esse ponto, mas claramente as investigações genéticas podem levar à identificação dos parentescos biológicos, embora o elemento socioafetivo possa, em casos particulares, sobrepujar essa vinculação.

10 Tratam-se dois princípios igualmente valorados pela Constituição Federal de 1988, na medida em que aponta no Art. 226, que a família deve receber especial proteção do Estado e que, além disso, ressalta no Art. 227 o dever da família e do Estado em assegurar, entre outros, que a criança e o adolescente tenham acesso à dignidade, ao respeito e a liberdade, prevenindo-os de qualquer tipo de exploração ou violência, o Art. 93 menciona no inciso IX o direito à intimidade, obrigando mesmo as autoridades judiciárias a manter sigilo de informações com exceção apenas aos casos de interesse público na informação (Disponível em: <http://www.planalto.gov.br/ccivil_03/constituicao/constituicao.htm>. Acesso em: 28/01/2015).
}

PRACS: Revista Eletrônica de Humanidades do Curso de Ciências Sociais da UNIFAP https://periodicos.unifap.br/index.php/pracs ISSN 1984-4352 Macapá, v. 12, n. 1, p. 49-63, jan./jun. 2019 


\section{MARIA E A RELAÇÃO DE INCESTO}

Em que pese a possibilidade de quebra do direito à intimidade por meio da divulgação de informações incidentais sobre os indivíduos, as famílias formadas por um grande número de membros e que são afetadas por doenças são de extrema relevância para as descobertas no campo da genética, pois a investigação permite o mapeamento dos genes e a compreensão do seu papel na progressão das doenças. Auxiliando, portanto, no desenvolvimento da pesquisa básica sobre o genoma humano e as doenças genéticas (cf. ZATZ, 2011, p. 28). A família, por sua vez, beneficia-se através do aconselhamento genético, devido à possibilidade de prevenção do nascimento de novos afetados e pela melhoria da qualidade de vida dos pacientes (cf. ZATZ, 2011, p. 30), tendo acesso à tecnologia de ponta e aos resultados mais recentes obtidos pelos pesquisadores (cf. ZATZ, 2011, p. 28). Assim, desenvolve-se entre os responsáveis pelo aconselhamento genético e os pacientes e familiares uma relação de benefícios para ambas as partes.

Porém, há casos em que a interação entre a pesquisa básica, que tem como fim o mapeamento de genes e a descoberta de seu funcionamento no desenvolvimento das doenças, e os pacientes e familiares investigados, é mais conflituosa. Além dos casos relatados que envolveram os pacientes Sônia e Pedro, também o caso de Maria, grávida aos 15 anos e que tinha dois irmãos acometidos pela distrofia de Duchenne. Ela buscou o aconselhamento genético, pois a doença se manifesta apenas em indivíduos do sexo masculino, afetando sua estrutura neuromuscular, sendo “(...) progressiva e degenerativa” (ZATZ, 2011, p. 49). Em dois terços dos casos a mãe transmite os genes embora seja uma “(...) portadora clinicamente normal” (ZATZ, 2011, p. 50).

O primeiro passo da investigação genética precisava determinar se Maria era ou não portadora do gene e, para tanto, foram realizados testes em seus pais. Concluiu-se que Maria era portadora apresentando um risco de $50 \%$ de que crianças do sexo masculino por ela geradas fossem afetadas. No entanto, o conflito ético mais grave surgiu a partir de uma informação incidentalmente obtida e que, em sua fonte, nem sequer tinha relação com o escaneamento genético. A informação, em princípio um rumor, era de que o próprio pai havia engravidado a adolescente (cf. ZATZ, 2011, p. 50), trazendo a tona não apenas a possibilidade de que a criança gerada desenvolvesse a distrofia de Duchenne, como também outras doenças genéticas relacionadas a situações de incesto. Para os responsáveis pelo atendimento restava, então, a dúvida de se, além dos testes genéticos já realizados, eles deveriam também realizar testes de paternidade (cf. ZATZ, 2011, p. 51).

Após discussão entre os responsáveis pelo atendimento o teste de paternidade foi finalmente realizado e descobriu-se que, de fato, o filho era fruto da relação incestuosa entre pai e filha menor de idade, sendo que a mãe desconhecia esse fato (cf. ZATZ, 2011, p. 51). A divulgação dessa informação, portanto, tenderia a destruir aquela unidade familiar, sendo que nela o pai era o provedor, inclusive sustentando os dois filhos, irmãos de Maria, que apresentavam a distrofia de Duchenne. Os geneticistas esclareceram à paciente Maria sobre o agravamento de riscos outras doenças genéticas para filhos gerados a partir de relações incestuosas, embora aquela criança que gestava não apresentasse o gene da distrofia. Além disso, os geneticistas optaram pela manutenção do sigilo sobre o incesto (cf. ZATZ, 2011, p. 52).

O caso de Maria possui vários níveis de complexidade. O primeiro é o nível relativo à intimidade do indivíduo e que foi a perspectiva privilegiada pelos geneticistas, pois eles 
consideraram mais importante a manutenção do sigilo da informação do incesto para os membros não diretamente ligados a ele, proporcionando, assim, a manutenção daquela unidade familiar. Note-se, no entanto, que o incesto foi considerado um problema maior para a unidade familiar do que a violência praticada contra a menor. O segundo é o nível do interesse público que, combinada à especial proteção dirigida à criança e ao adolescente, poderia ter sido utilizado como argumento para o relato do incesto para as autoridades competentes, de modo que fosse aberta uma investigação criminal para apurar a relação incestuosa que havia se montado entre Maria e seu pai. ${ }^{11}$

Isso porque, no Brasil, a prática de conjunção carnal com criança ou adolescente com idade entre 14 e 17 anos é considerado presumidamente estupro. ${ }^{12}$ Além disso, o estupro seria agravado pelo caso de incesto uma vez que pai não exerceu a paternidade responsável e preservando, assim, a dignidade de sua descendente. ${ }^{13}$ Assim, pelo fato de existir o interesse público de proteção da família e também da criança e do adolescente, haveria motivos para a informação das autoridades, para que o caso de incesto fosse devidamente investigado. Porém, vimos que essa não foi a decisão dos geneticistas em relação à situação em que Maria esteve envolvida.

Podemos comparar essa situação com casos em que o profissional é, na verdade, obrigado a informar as autoridades, situação essa que vai, portanto, de encontro ao sigilo profissional. ${ }^{14}$ É o que está previsto no Código de Ética Profissional do Psicólogo, segundo o qual é possível haver quebra de sigilo no caso de busca do menor prejuízo. ${ }^{15}$ Assim, resta a questão de se a decisão de preservar o sigilo, tendo em vista a proteção à intimidade foi, de fato, a melhor decisão possível a ser tomada no caso do atendimento de Maria, mantendo como objetivo relevante necessidade de a proteção da criança e do adolescente. Embora considerando que a motivação inicial para que Maria buscasse o aconselhamento genético, ou seja, a questão de se seu filho não era portador da distrofia de Duchenne tenha tido um desfecho positivo, vez que o mesmo não era portador, talvez a decisão de manter o sigilo sobre a informação incidentalmente obtida acerca do incesto, tenha levado à manutenção de uma relação de abuso em relação à Maria, contra a qual ela ainda não tivesse plena capacidade de resistir ou modificar. Desenvolveremos ainda mais essa questão no item seguinte.

\footnotetext{
11 O Estatuto da Criança e do Adolescente prevê a criação dos Conselhos Tutelares em cada município e em cada região administrativa do Distrito Federal, que apresentam, entre suas atribuições, zelar pelo cumprimento dos direitos das crianças e dos adolescentes (Art. 131), bem como atender às crianças e adolescentes em casos de ameaça ou efetiva violação dos seus direitos (Art. 136, I), o que inclui medidas de proteção diante de falta, omissão ou abuso dos pais ou responsáveis (Art. 98, II). Assim, esse seria o órgão por excelência para o qual encaminhar Maria. Disponível em: <http://www.planalto.gov.br/ccivil_03/Leis/18069.htm>. Acesso em: 03/06/2015. Agradeço à doutoranda em serviço social Alessandra Genú Pacheco pela inclusão dessa informação.

12 Decreto-lei no 2.848, de 07/12/1940 (Código Penal Brasileiro), Art. 213, \$1 . Disponível em: <http://www.planalto.gov.br/ccivil_03/decreto-lei/del2848compilado.htm>. Acesso em: 28/01/2015.

13 Constituição Federal de 1988 define no Art. 226, $\int 7^{\circ}$ como princípios dessa proteção à família oferecida pelo Estado à dignidade da pessoa humana e à paternidade responsável (Disponível em: < http://www.planalto.gov.br/ccivil_03/constituicao/constituicao.htm>. Acesso em: 28/01/2015).

$14 \mathrm{O}$ Art. $9^{\circ}$, do Código de Ética Profissional do Psicólogo prescreve o dever de sigilo profissional, para que sejam preservadas a intimidade das pessoas, grupos ou instituições a que venha a ter acesso (Disponível em: < http://site.cfp.org.br/ documentos/confira-o-novo-codigo-de-etica-profissional-do-psicologo/>. Acesso em: 28/01/2015).

15 Art. 10, Código de Ética Profissional do Psicólogo (Disponível em: <http://site.cfp.org.br/documentos/confira-onovo-codigo-de-etica-profissional-do-psicologo/>. Acesso em: 28/01/2015).
} 


\section{SIGILO MÉdICO, INTIMIDAdE E PROTEÇÃo À FAMÍlIA VERSUS PROTEÇÃO DA CRIANÇA E DO ADOLESCENTE}

Os três casos apresentados de atendimento de Sônia, de Pedro e de Maria possuem certa gradação quanto à complexidade, quanto ao impacto social das informações incidentalmente obtidas e quanto aos conflitos de valores que emergem em cada caso. Isso porque, enquanto o caso de Sônia apontou para a falsa paternidade apenas em relação ao seu pai, a família de Pedro lidou com a difícil informação de que tanto seu pai, quanto sua mãe não eram seus pais biológicos, fato esse desconhecido por eles até a realização do escaneamento genético. Ainda que ao levantar questões complexas para os seus respectivos agrupamentos familiares, observamos que os efeitos das informações de falsa paternidade obtidos nos dois casos incidiram especialmente sobre aquelas famílias em particular. Em tais casos, caberia questionarmos, por exemplo, sobre a legitimidade da decisão tomada pelos responsáveis pelo atendimento de Sônia e de Pedro no aconselhamento genético, sobretudo quanto à divulgação dos casos de falsa paternidade.

Parece-nos, no entanto, que o atendimento de Maria eleva em grau de complexidade e aumenta também proporcionalmente o interesse público no caso. Assim, utilizaremos esse atendimento como exemplar para a discussão que detalharemos a seguir dos diferentes valores que estão em jogo, especialmente quanto ao dever de sigilo médico, de manutenção da intimidade do indivíduo e também quanto à proteção à família versus a proteção à criança e ao adolescente. Dessa maneira, buscamos mostrar que existe certa margem de interpretação mesmo nos dispositivos legais brasileiros que são, por sua vez, carregados de valores socialmente estimados. Assim, tanto o profissional que lida com o aconselhamento genético, quanto às famílias atendidas, precisam ter acesso à articulação dos valores envolvidos quando da obtenção de informações incidentais à investigação genética. Embora, como veremos, quanto ao caso específico de Maria, consideramos que os responsáveis pelo aconselhamento genético deveriam ter informado à mãe e as autoridades cabíveis sobre a relação incestuosa que se instaurara naquela família, em busca do menor dano moral possível à paciente.

Podemos considerar que a dinâmica social básica, ou seja, aquela em que oferecemos razões para nossas ações ou decisões de modo a que possam ser ouvidas e avaliadas pelos demais, foi adotada entre os responsáveis pelo atendimento de Maria no CEGH-CEL diante da questão ética derivada da informação incidental sobre o incesto. Desse modo, para “(...) atingir a cooperação, precisamos perseguir as questões conjuntamente, para determinar 'como única mente' sobre as soluções" (BLACKBURN, 2003, p. 111). Embora realizando tal procedimento para a decisão da questão prática sobre a quebra ou não da confidencialidade, consideramos que com base em outras razões, outra solução poderia ter sido dada ao caso.

Primeiramente, então, cabe ressaltar que o valor apresentado no topo da hierarquia nos três casos que é o do sigilo médico. Assim, a decisão de divulgar as informações incidentais sobre a falsa paternidade foi deixada, no caso de Sônia, a cargo da mãe, a quem caberia, portanto, a decisão de relevar ou não à filha que aquele que até então considerara como pai, na verdade, não tinha parentesco biológico com ela. Quanto ao caso de Pedro, não fica tão claro no relato se a divulgação da falsa paternidade partiu de decisão tomada pelos responsáveis pelo atendimento, ou se se chegou a essa informação incidental depois do processo de aconselhamento. E, quanto ao caso de Maria, a decisão quanto a não revelar para a mãe sobre a relação incestuosa que era mantida entre pai e filha foi tomada pelos responsáveis pelo aconselhamento 
genético.

O Código de Ética Médica apresenta vários dispositivos que podem ser relacionados à análise da solução de manter o sigilo no atendimento de Maria. Cabe apresentar, então, o valor que foi considerado como central na decisão sobre a não divulgação do incesto, que é o do sigilo médico, reforçado ainda pela proteção à intimidade e à família. Segundo o Código de Ética Médica, é vedado ao médico: "Revelar fato de que tenha conhecimento em virtude do exercício de sua profissão, salvo por motivo justo, dever legal ou consentimento, por escrito, do paciente" (Art. 73, Código de Ética Médica). Além disso, a Lei no 10.241, de 17/03/1999, que trata dos direitos usuários dos serviços e das ações de saúde no Estado de São Paulo, afirma também que deve ser assegurado ao paciente em consultas, internações, procedimentos diagnósticos e terapêuticos “(...) a confidencialidade de toda e qualquer informação pessoal” (XIV, alínea “e”, Lei no 10.241, de 17/03/1999).

Como é possível constatar, o sigilo médico visa à proteção da intimidade do paciente que se encontra no diagnóstico, no tratamento, no atendimento, e demais procedimentos médicos, em situação de vulnerabilidade. Assim, aqueles que obtêm informações privilegiadas sobre o mesmo devem evitar em máxima medida possível a exposição sobre seu estado clínico, pois, como vimos, a divulgação de tal informação pode acarretar reações preconceituosas, além de outras consequências. Mas, como toda regra, o sigilo médico também encontra algumas exceções. A própria Lei no 10.241, de 17/03/1999 apresenta dois casos em que o sigilo médico poderia ser quebrado, que são os casos de riscos a terceiros e à saúde pública (cf. IV, Lei $\mathrm{n}^{\circ}$ 10.241, de 17/03/1999).

Caso recente que abarca as duas situações do risco a terceiros e à saúde pública nacional e internacional, foi o surto de Ebola em 2014. Caracterizado como epidemia, com risco de desenvolvimento de uma pandemia, ou seja, com potencial de atingir várias partes do mundo ao mesmo tempo, devido à rápida propagação do microrganismo e também ao fato de que doença ainda não possuía cura (cf. LOPES \& DUNDA, 2015, p. 3). Segundo Gills Vilar Lopes e Fabíola Dunda, o Ebola fomentou a cooperação internacional, uma vez que a doença já havia infectado no oeste africano em agosto de 2014 mais de nove mil pessoas, levando aproximadamente 50\% dos infectados ao óbito (cf. LOPES \& DUNDA, 2015, p. 4). Claramente, esse é um caso que mostra o interesse público na informação sobre o diagnóstico obtido.

No entanto, via de regra, o sigilo médico é colocado como um dos principais valores no Código de Ética Médica, pois o médico “(...) guardará absoluto respeito pelo ser humano e atuará sempre em seu benefício. Jamais usará os seus conhecimentos para causar o sofrimento físico ou moral (...)” (VI, Código de Ética Médica); e também “(...) guardará sigilo a respeito das informações de que detenha conhecimento no desempenho de suas funções" (XI, Código de Ética Médica). Dessa maneira, é possível observar a relação entre o tratamento digno depende, pelo menos em parte, da manutenção do vínculo de confiança formado entre médico e paciente, cujo reforço é proporcionado pelo sigilo.

Porém, no caso do atendimento da Maria, não era apenas a relação entre médico e paciente que estava em jogo. Pois, além da paciente, estavam envolvidos também os seus familiares, especialmente o pai, com quem supostamente mantinha a relação de incesto, ${ }^{16}$ e a mãe, que

\footnotetext{
16 Utilizamos aqui o termo "supostamente", pois embora o teste de paternidade realizado no CEGH-CEL tenha apontado que o pai de Maria era também o pai biológico do embrião que Maria gestava, no Direito, para que um ato seja considerado crime, é necessário um julgamento prévio e, portanto, uma sentença transitada em julgado que ateste aquela ação como criminosa e sujeita às penalidades legais (LVII, Constituição Federal de 1988).
}

PRACS: Revista Eletrônica de Humanidades do Curso de Ciências Sociais da UNIFAP https://periodicos.unifap.br/index.php/pracs ISSN 1984-4352 Macapá, v. 12, n. 1, p. 49-63, jan./jun. 2019 
desconhecia essa situação; e, além disso, deve-se levar em conta a questão de que Maria era menor de idade quando levada ao aconselhamento genético. Daí que seja necessário abordar também a proteção especialmente dirigida pela Constituição Federal à família, à criança e ao adolescente, bem como levar em consideração o Estatuto da Criança e do Adolescente.

A Constituição Federal de 1988 na parte dedicado aos direitos sociais, afirma entre os direitos dos trabalhadores rurais e urbanos o salário mínimo capaz de suprir as necessidades não apenas do próprio trabalhador, mas também de sua família, necessidades essas que compreendem “(...) moradia, alimentação, educação, saúde, lazer, vestuário, higiene, transporte e previdência social” (Art. $7^{\circ}$, IV, Constituição Federal de 1988). Além da preocupação com esses elementos-chave para a manutenção de uma vida digna, também na parte relativa à assistência social, a Constituição Federal dirige especial atenção à proteção “(...) à família, à maternidade, à infância, à adolescência e à velhice” (Art. 203, I, Constituição Federal de 1988). E, como corolário, enfatiza a família como base da sociedade e a quem o Estado direciona especial proteção (cf. Art. 226, Constituição Federal de 1988).

Assim, conjugando o dever de sigilo médico com a proteção especial que o Estado brasileiro dirige à família, estaríamos inclinados a considerar que a decisão tomada pelos responsáveis pelo aconselhamento genético de Maria de não divulgar a situação de incesto para os familiares não envolvidos diretamente no caso como a decisão correta. Isso porque tal decisão levou em consideração a proteção da intimidade dos indivíduos envolvidos na relação incestuosa, ${ }^{17}$ bem como os possíveis impactos negativos sobre a manutenção daquela unidade familiar, tendo em vista que o pai em questão era seu provedor.

No entanto, é possível também, com base em outra perspectiva de valor apresentada por dispositivos legais vigentes no Brasil, demonstrar o argumento em contrário, ou seja, de que seria mais aconselhável no caso em questão a divulgação da informação incidental sobre o incesto não apenas para a mãe de Maria, mas também para autoridades competentes aptas à investigação. Após a apresentação da família como portadora do direito de proteção especial pelo Estado (Art. 226, Constituição Federal de 1988), o artigo seguinte trata dos deveres da família e do Estado em relação à criança, ao adolescente e ao jovem, aos quais devem assegurar

(...) com absoluta prioridade, o direito à vida, à saúde, à alimentação, à educação, ao lazer, à profissionalização, à cultura, à dignidade, ao respeito, à liberdade e à convivência familiar e comunitária, além de colocá-los a salvo de toda e qualquer forma de negligência, discriminação, exploração, violência, crueldade e opressão (Art. 226, Constituição Federal de 1988).

Gostaríamos de destacar em especial o dever da família e do Estado na proteção da criança, do adolescente e do jovem em relação à exploração, à violência e à crueldade. O Estatuto da Criança e do Adolescente define como adolescente, a pessoa que apresenta entre 12 e 18 anos de idade (Art. $2^{\circ}$, Lei no 8.069, de 13/07/1990), pois é a partir dos 18 anos (ou por emancipação) que a pessoa se torna apta a responder no âmbito civil e penal por seus atos, o que significa que, para questões jurídicas, ela atingiu a maioridade. ${ }^{18}$ Antes da realização efetiva desse

17 O Art. 5 , x, da Constituição Federal de 1988 apresenta a inviolabilidade da intimidade, da vida privada, da honra e da imagem das pessoas, assegurando a possibilidade de indenização por dano moral ou material advindo de seu desrespeito (Disponível em: <http://www.planalto.gov.br/ccivil_03/constituicao/constituicao.htm>. Acesso em: 28/01/2015).

18 Art. $5^{\circ}$ do Código Civil afirma que a “(...) menoridade cessa aos dezoito anos completos, quando a pessoa fica habilitada a prática de todos os atos da vida civil” (Disponível em: < http://www.planalto.gov.br/ccivil_03/leis/2002/110406. htm>. Acesso em: 07/06/2015); embora esse não seja o único modo através do qual cessa a incapacidade jurídica de 
requisito, o menor está sob a guarda de seus responsáveis legais, sendo esses na maior parte das vezes os seus pais.

Dentre o rol de deveres que os pais assumem em relação aos seus descendentes está o de proporcionar seu “(...) desenvolvimento físico, mental, moral, espiritual e social, em condições de liberdade e de dignidade" (Art. $3^{\circ}$, Estatuto da Criança e do Adolescente). E, além disso, o estatuto estabelece como invioláveis o respeito à “(...) integridade física, psíquica e moral da criança e do adolescente, abrangendo a preservação da imagem, da identidade, da autonomia, dos valores, ideias, crenças (...)" (Art. 17, Estatuto da Criança e do Adolescente). Caberia, então, questionarmos se o valor mais importante no caso do atendimento de Maria seria o da manutenção de sua imagem, compreendida como decorrência da proteção à intimidade, ou da proteção de seu desenvolvimento digno, já que o incesto pode ser considerado como uma forma de tratamento degradante; além, é claro, de uma falta grave cometida pelo pai, a quem compete, juntamente com a mãe, o exercício do poder familiar tendo em vista os deveres de sustento, de guarda e de educação dos filhos (Art. 20 e Art. 21, Estatuto da Criança e do Adolescente).

Assim, particularmente quanto ao caso das informações incidentais obtidas no aconselhamento genético de Maria, que fortemente indicavam uma situação de incesto, consideramos que, para além do interesse privado de manutenção da intimidade da paciente e de seu pai, está o interesse público de proteção especial atestado pela Constituição Federal de 1988 e do Estatuto da Criança e do Adolescente. Embora levando em consideração a ampla experiência do CEGH-CEL no atendimento de famílias acometidas por determinadas condições genéticas, consideramos que os valores do sigilo médico, da intimidade e da proteção à família acabam por ficar em segundo plano em relação à proteção à adolescente.

Parece-nos que, especificamente quanto ao caso do sigilo em relação ao incesto provocou a manutenção de uma situação degradante de exploração de uma menor de idade, cujas consequências poderão ser sentidas não apenas por Maria, como também pelo filho que veio a termo em um núcleo familiar que violou seus direitos. E, além disso, há claramente o interesse público de que, uma vez que os responsáveis por sua guarda não exerceram corretamente o poder familiar, o Estado poderia ser acionado para averiguar e buscar uma solução que estivesse mais de acordo com a preservação da vida digna de Maria.

\section{CONSIDERAÇÕES FINAIS}

Consideramos que a aplicação de tecnologias é uma prática social histórica permeada por valores. O momento da atividade científica parece-nos especialmente propício para a visualização das conexões entre os problemas éticos e as soluções baseadas nos valores sociais, bem com para explorar os conflitos de valores que podem advir dessas aplicações. Os três casos de aconselhamento genético realizados pelo CEGH-CEL foram, assim, utilizados para o exercício da articulação dos valores sociais considerados em alta estima, bem como para proporcionar a formação de um senso crítico em relação às consequências indesejadas que podem advir da realização da medicina preventiva com foco no aconselhamento genético e, em especial, quanto às informações incidentais adquiridas por sua aplicação.

menor. E, além disso, o Art. 27 do Código Penal afirma que os “(...) menores de 18 (dezoito) anos são penalmente inimputáveis, ficando sujeitos às normas estabelecidas na legislação especial” (Art. 27, Código Penal. Disponível em: <http://www.planalto.gov.br/ccivil_03/decreto-lei/del2848compilado.htm>. Acesso em: 28/01/2015).

PRACS: Revista Eletrônica de Humanidades do Curso de Ciências Sociais da UNIFAP https://periodicos.unifap.br/index.php/pracs ISSN 1984-4352 Macapá, v. 12, n. 1, p. 49-63, jan./jun. 2019 
A solução para os conflitos entre valores (por exemplo, sigilo versus dignidade) não possuem uma solução única e mesmo restrita às instituições que realizam o aconselhamento genético. Tais instituições, embora prestando um serviço inestimável à sociedade e cuja ação está orientada por sua ampla experiência prática, estão inseridas em contexto social mais amplo. Desse modo, as práticas que realizam e as soluções que obtêm nos conflitos de sua prática estão sujeitas à discussão pública.

Os casos de Sônia, de Pedro e de Maria assemelham-se tanto por terem suscitado informações incidentais quanto pelo sigilo médico, com a consequente proteção da intimidade do paciente e dos familiares, ter sido colocado em primeiro plano. Assim, mesmo que com o atendimento de Sônia tenha-se obtido a informação de falsa paternidade em relação ao seu pai, e que o caso de Pedro tenha levado ao reconhecimento da falsa paternidade em relação ao pai e à mãe, os responsáveis por seus atendimentos optaram por deixar que os próprios familiares decidissem se revelariam ou não a falsa paternidade aos seus descendentes.

No entanto, parece-nos que entre os três casos, o de Maria se mostrou mais complexo, na medida em que a não revelação da situação de incesto que se instaurou naquela família pode ter levado à consequência do dano maior, e não menor, a Maria. Isso por que, embora o pai fosse o provedor da família, que já apresentava dois portadores da distrofia de Duchenne, no que diz respeito à proteção em relação a Maria esses pais faltaram com seus deveres em diferentes graus: mais gravemente o pai por ter mantido relações sexuais com filha menor de idade (o que leva, entre outros problemas, a questão de se tal relação foi ou não consensual), mas também a mãe por negligência. No entanto, a própria definição dos graus de responsabilização dependeria de uma investigação pela autoridade pública, durante o qual o Conselho Tutelar poderia impor medidas para que os direitos de Maria não continuassem a ser violados.

Portanto, parece-nos que no caso de Maria, e levando em consideração o interesse público na investigação de situações potencialmente danosas ao desenvolvimento e ao exercício da vida digna, a proteção à criança e ao adolescente deveria ter sido colocada no topo da hierarquia dos valores, sobrepujando, assim, o sigilo médico, a proteção à intimidade dos indivíduos envolvidos e à família.

Reafirmamos que o objetivo aqui não é o de descaracterizar a importância do aconselhamento genético realizado pelo CEGH-CEL, nem julgar a capacidade técnica e a sensibilidade ética dos envolvidos nesse serviço prestado à sociedade. Nossa pretensão é a de mostrar que mesmo as atividades biotecnológicas exercidas com imparcialidade e objetividade, como é o caso do aconselhamento genético, podem levar a conflitos entre os valores sociais diversos. E, para essas situações conflituosas, o reconhecimento da interação entre a ciência e os valores sociais, a capacidade de articulá-los e o conhecimento de determinados dispositivos legais vigentes (também carregados de valores), podem vir ao auxílio da solução menos danosa aos envolvidos.

Enquanto autora, agradecemos ao financiamento da Capes/Proex recebido por meio da bolsa de doutorado em Filosofia da USP (conclusão em 2015) sob a orientação atenciosa do Prof. Dr. Pablo Rubén Mariconda, sendo esse artigo um dos seus resultados. Aos comentários feitos pelos participantes XII Congresso Afro-Luso-Brasileiro (01 a 05 de fevereiro de 2015, Lisboa, Portugal, FCSH/ NOVA), momento em que apresentei a primeira versão deste artigo. E, finalmente, ao Prof. Dr. Hugh Lacey por acompanhar meu desenvolvimento acadêmico e por suas preciosas críticas e sugestões ao artigo. 


\section{REFERÊNCIAS}

AYMORÉ, Débora. Progresso valorativo da ciência e a biotecnologia: sobre a participação dos valores sociais na avaliação do progresso científico. 2015. 204 f. Tese (Doutorado) - Faculdade de Filosofia, Letras e Ciências Humanas. Departamento de Filosofia, Universidade de São Paulo, São Paulo, 2015.

O Projeto Semear e o uso da imagem na divulgação da biotecnologia. In: V Encontro Nacional de Estudos da Imagem [e do] II Encontro Internacional de Estudos da Imagem [livro eletrônico]. Londrina: Universidade de Londrina, 2015. V. 3, p. 28-45.

BIBLIOTECA VIRTUAL EM SAÚDE. Disponível em: <http://bvsms.saude.gov. br/bvs/dicas/180_teste_pezinho.html >. Acesso em 17/05/2015.

BLACKBURN, Simon. Ethics. New York: Oxford University Press, 2003 (A very short introduction).

BRASIL 1940. Código Penal. Decreto-Lei no 2.848, de 07 de dezembro de 1940. Disponível em: <http://www.planalto.gov.br/ccivil_03/decreto-lei/del2848.htm>. Acesso em: 28/01/2015.

BRASIL 1988. Constituição Federal de 1988. Constituição da República Federativa do Brasil. Disponível em: <http://www.planalto.gov.br/ccivil_03/constituicao/constituicao.htm>. Acesso em: 21/01/2014.

BRASIL1990. Estatuto da Criança e do Adolescente. Lei no 8.069, de 13 de julho de 1990. Dispõe sobre o Estatuto da Criança e do Adolescente e dá outras providências. Disponível em: <http://www.planalto.gov.br/ccivil_03/Leis/18069.htm>. Acesso em: 03/06/2015.

BRASIL 2002. Código Civil. Lei $\mathrm{n}^{\circ}$ 10.406, de 10 de janeiro de 2002. Disponível em: <http://www.planalto.gov.br/ccivil_03/leis/2002/110406.htm>. Acesso em: 07/06/2015.

BRASIL 2004. Lei no 10.973 , de 02 de dezembro de 2004. Dispõe sobre incentivos à inovação e à pesquisa científica e tecnológica no ambiente produtivo e dá outras providências. Disponível em: <http://www.planalto.gov.br/ccivil_03/_ato2004-2006/2004/lei/110.973.htm> Acesso em 14/12/2014.

CONSELHO FEDERAL DE PSICOLOGIA. Resolução CFP no 010, de 21 de julho de 2005. Aprova o Código de Ética Profissional do Psicólogo. Disponível em: $<$ http://site.cfp.org.br/documentos/confira-o-novo-codigo-de-etica-profissional-do-psico$\log$ / $>$. Acesso em 28/01/2015.

CONSELHO REGIONAL DE MEDICINA DO ESTADO DE SÃO PAULO. Resolução CFM no 1.931, de 17 de setembro de 2009. Aprova o Código de Ética Médica, anexo a esta resolução, após sua revisão e atualização. Disponível em: <https://www.cremesp.org.br $/$ ?siteAcao $=$ Publicacoes\&acao $=$ detalhes\&cod_publicacao $=73>$. Acesso em 15/05/2015.

CONSULTOR JURÍDICO. STF decidirá sobre paternidade socioafetiva e biológica. Disponível em: <http://www.conjur.com.br/2013-jan-17/stf-decidira-disputa-entre-paternidade-socioafetiva-biologica $>$. Acesso em: 06/11/2015.

ESTADO DE SÃO PAULO 1999. Lei no 10.241, de 17 de março de 1999. Dispõe sobre os direitos dos usuários dos serviços e das ações de saúde no Estado e dá outras providências. Disponível em: $<$ https: $/ /$ www.cremesp.org.br $/$ ?siteAcao $=$ Publicacoes\&acao $=$ detalhes\&cod_publicacao $=73>$. Acesso em 15/05/2015.

FERREIRA, Mariana Toledo. A institucionalização da pesquisa em genética no Brasil e 
seus pesquisadores: um estudo de caso do Centro de Estudos do Genoma Humano da USP. São Paulo, 2013. 203 f. Dissertação (Mestrado). Faculdade de Filosofia, Letras e Ciências Humanas. Departamento de Sociologia, Universidade de São Paulo, 2013.

HABERMAS, Jürgen. The future of human nature. Cambridge/UK: Polity Press, 2012 [2003].

KUHN, Thomas S. The structure of scientific revolutions. 2 ed. Chicago: University of Chicago Press, 1970 [1962].

Postscript. In: . The structure of scientific revolutions. 2 ed. Chicago: University of Chicago Press, 1970a [1969], p. 174-210.

LACEY, Hugh. Valores e atividade científica 1. 2 ed. São Paulo: Associação Filosófica Scientiae Studia/ Editora 34, 2008.

Ciência e valores. In: Valores e atividade científica 1. 2 ed. Tradução E. S. de O. Barra. São Paulo: Associação Filosófica Scientiae Studia/ Editora 34, 2008a [1997], p. 1945.

Para uma análise dos valores. In: - Valores e atividade científica 1. 2 ed. Tradução C. E. O. Miranda. São Paulo: Associação Filosófica Scientiae Studia/ Editora 34, 2008b[1997], p. 47-82.

A dialética da ciência e da tecnologia avançada: uma alternativa? In:

Valores e atividade científica 1. 2 ed. Tradução M. B. de Oliveira. São Paulo: Associação Filosófica Scientiae Studia/ Editora 34, 2008c, p. 189-216.

Valores e atividade científica 2. São Paulo: Associação Filosófica Scientiae Studia/ Editora 34, 2010.

A localização social das práticas científicas. In: - Valores e atividade científica 2. Tradução R. R. Kinouchi. São Paulo: Associação Filosófica Scientiae Studia/ Editora 34, 2010a [2006], p. 57-99.

- A ciência e o bem-estar humano: uma nova maneira de estruturar a atividade científica. In: Valores e atividade científica 2. Tradução M. I. R. e S. Lacey. São Paulo: Associação Filosófica Scientiae Studia/ Editora 34, 2010b [2003], p. 101-27.

- Alternativas para a tecnociência e os valores do Fórum Social Mundial. In: Valores e atividade científica 2. Tradução L. C. B. de Oliveira. São Paulo: Associação Filosófica Scientiae Studia/ Editora 34, 2010c [2002], p. 175-202.

LACEY, Hugh. \& MARICONDA, Pablo Rubén. O modelo da interação entre as atividades científicas e os valores na interpretação das práticas científicas contemporâneas. Estudos Avançados, 28 (82), 2014, p. 181-99.

. O modelo da interação entre as atividades científicas e os valores. Scientiae Studia, v. 12, n. 4, 2014a, p. 643-68.

MANUAL MERCK. Disponível em: <http://www.manualmerck.net/>. Acesso em 17/05/2015.

PROJETO SEMEAR. Disponível em: < http://www.ib.usp.br/biologia/projetosemear/diferentes/>. Acesso em: 26/03/2015.

SANDEL, Michael J. Contra a perfeição: ética na era da engenharia genética. Tradução A. C. Mesquita. Rio de Janeiro: Civilização Brasileira, 2013 [2007].

ZATZ, Mayana. Genética: escolhas que nossos avós não faziam. São Paulo: Editora Globo, 2011. 